\title{
How is space public? Implications for spatial policy and democracy
}

\author{
John R Parkinson \\ Department of Politics and International Studies, University of Warwick, Coventry CV4 7AL, \\ England; e-mail: J.R.Parkinson@warwick.ac.uk \\ Received 17 August 2011; in revised form 20 July 2012
}

\begin{abstract}
Battles over public space involve conflicts of values that express themselves in planning policies as well as the built environment. However, the dominant conceptions of public space in planning practice and the academic literature support a limited range of those values. I argue that conceptions based on openness and accessibility play into a particular construction of public life that emphasises casual interactions and downplays purposive, political ones. Following a conceptual analysis of the public-private distinction, the paper offers a novel, threefold account of public space; argues that democracy requires a particular kind of publicness not recognised by the commonly accepted definition; and deploys a simple content analysis to highlight the conceptual emphases and absences in planning policy in the political heart of London. I argue that some advocates of public space are unwittingly supporting restrictive planning and design practices that limit important kinds of democratic expression.
\end{abstract}

Keywords: public, private, space, democracy, London, protest

\section{Introduction}

Public space in major cities has long been the site of policy contestation. Planners have been driving spatial strategies that emphasise the health, environmental, and community benefits that are said to come from particular approaches to the built environment, valuing relatively intimate spaces with lots of furniture and planting to encourage people to stop, sit, and interact (eg, CABE, 2002; Sennett, 2002). City development officials have tried to use large open spaces for entertainment and spectacle (eg, NCC, 2005), have handed over the management of sidewalks and promenades to local business associations keen to increase foot traffic past their premises (Dovey, 2004; Schaller and Modan, 2005), or have downplayed inner-city space and focused on peripheral shopping malls (Kohn, 2001). Security officials have been promoting an approach that seeks to enhance the security of public figures by a combination of wide, open, and surveillable spaces around public buildings plus perimeter security provided not by jersey barriers but by trees and urban furniture, as well as TV cameras and patrols (eg, Benton-Short, 2007; NCPC, 2005; Vale, 2005). Citizens themselves use public space for an enormous range of purposes - places to stop for a sandwich, to play, to walk the dog, to get from A to B, to people-watch, to read a book, to skateboard, to feed the ducks, to reconnect with nature, to reconnect with memories via memorials, to feel part of a collective enterprise, to demonstrate, to display, to meet, to sleep ... the list could go on (cf Burgess et al, 1988; Iveson, 2007).

These strategies and uses are conflicting. Space that is good for quiet contemplation of nature is often not good for mass events; space that is secure is often not good space for casual interaction; space that is good for demonstrating is not good space for commercial needs. Thus, these conflicts matter when it comes to decisions about the design and management of urban public space. 
Given all that complexity and contestation, it is not surprising that the planning literature has developed critiques of the dominant spatial planning agendas (especially Allmendinger and Haughton, 2010; see also Baker et al, 2010; Gallent and Wong, 2009). What is much more surprising is that various branches of the literature have settled on relatively straightforward definitions of public space - definitions that focus on some uses and filter out others. Minimally, definitions focus on 'open and accessible' space (eg, GLA, 2011, page 47; Stevens, 2009). Urban scholars, reflecting a long-standing concern with the 'socialness' of the city experience from Simmel (1950) onwards, take that 'accessible' starting point and reflect on the variety of ways in which access to space is restricted and by whom, or by what forces and in whose interests restrictions are established, maintained, challenged, and loosened. This includes a reaction against the tendency in the planning profession to objectify space and treat human behaviour as a direct product of spatial arrangements, as opposed to space as being itself a social construct (see also Gieryn, 2000; Lehtovuori, 2010). Mainstream urban scholarship thus advances a competing normative vision of public space as sites for unscripted encounters between strangers (eg, Kohn, 2004; Lofland, 1998; Madanipour, 2003) rather than encounters scripted by landowners, business, and planners who serve their interests.

Valuable though those insights are, unscripted encounters between strangers cannot be all there is to public space, especially in democratic states. I argue that the standard definition reinforces a tendency to filter out expressly political concerns, the purposive collective action of citizens rather than their accidental encounters. The standard definition is insufficient for descriptive purposes because it fails to capture the full variety of often-incompatible ways in which public space is used. It is insufficient on normative grounds because it fails to provide sufficient reasons to justify certain kinds of democratic action and the space that is needed to perform those actions. To put it more sharply, while it is the case that many urban scholars decry the loss of space for purposive collective action (eg, Mitchell and Staeheli, 2005, page 798; Stevens, 2009), their very definition of public space provides only weak grounds on which to resist such losses.

The aim of this paper is to specify and clarify a political definition of public space that can be used to provide firmer ground for criticising planning and design for democratic engagement. I start with the standard public-private distinction and argue that the public and private labels mask several different distinctions. To go deeper, in sections 2 and 3 I supplement a sociological understanding of public space with a political account, resulting in a more nuanced, threefold definition of public space, such that spaces might exhibit three, two, or just one of the features and still be thought of as 'public'. In section 4 I develop the political element of the definition by setting out the spatial requirements for the performance of public roles in a democracy. In section 5 I then use a simple content analysis of a set of recent planning documents concerning London's central political zone to highlight the extraordinary degree to which political, democratic imperatives are not just downplayed but absent from urban spatial policy in the capital city of a major democracy.

I take an expressly liberal view of politics and democracy. This is because the publicprivate distinction is itself a liberal concept, albeit a much-criticised one; and because the institutions found in Western democracies are largely liberal ones. If an important purpose of analysis of public space is to criticise and modify spatial practices in liberal states, then it helps to start with arguments that already have some 'bite' in such states. I recognise that starting with a different account of politics and democracy might lead the analysis in different directions, both analytically and normatively. My aim here is more limited: to show that even a mainstream, liberal account of politics helps sharpen the critical tools that scholars of public space already have available. The conclusions in section 6 provide firmer normative 
ground on which to argue for access to particular sites for expressly political purposes; and reasons to rethink public spatial policies that are potentially disastrous for democracy, despite their advocates' best intentions.

\section{The public-private distinction}

Public space ${ }^{(1)}$ discussions often start by making a more general distinction between public and private, but rarely do such discussions delve into the origins and nature of the distinction. It is useful to do so in the present context, for two reasons. First, one aim of this paper is to clarify concepts from a liberal democratic point of view, and the public-private distinction has been a cornerstone of liberal politics and liberal democratic theory. Second, the nature of that cornerstone has been questioned in political theory for many years now; indeed, the very idea that there is a coherent distinction to be made has been called into question, and yet the vast majority of urban scholarship that starts with conceptual definitions continues to trade in standard binary distinctions. In this section I deal with the second of those points first, disrupting binary categories so that the concept of public space can be examined afresh.

Perhaps the clearest exposition of the problematic nature of the public-private distinction comes from Geuss (2001), and so it is worth quoting him at length:

"There is no such thing as the public/private distinction, or, at any rate, it is a deep mistake to think that there is a single substantive distinction here that can be made to do any real philosophical or political work .... it is not the case that we must or should adopt a two-step procedure, first getting clear about the public/private distinction, assuming all the while that there is a single distinction to be made, and then, having discovered where the line falls between public and private, going on to ask what we can do with that distinction, what attitude we should adopt toward it, what implications making the distinction correctly might have for politics. Rather, first we must ask what this purported distinction is for, that is, why we want to make it at all. To answer this question will bring us back to some relatively concrete context of human action, probably human political action, and it is only the context of connecting the issue of the public and private to that antecedent potential context of political action that the distinction will make any sense" (pages 106-107, original emphasis).

In other words, appeals to the publicity or privacy of something are actually appeals to other facts and values which are bundled up in the labels 'public' and 'private'. These include the following four broad categories:

(1) Freely accessible places where strangers are encountered whether one wants to or not, because everyone has free right of entry-as opposed to places that are not freely accessible, and that have controllers who limit access to or use of that space (page 52).

(2) The things that concern, affect, or are for the benefit of everyone-Arendt's (1958, page 52) second sense of 'public' - as opposed to things that primarily concern individuals, following Dewey (1924). This realm includes 'common goods' (Hardin, 1968) like clean air and water or public transport.

(3) The people or groups that have rights over or responsibility for the realm covered in 2 , which might include rulers, or 'public figures', or 'the public' as a noun rather than an adjective.

(1) It should be noted that throughout I use the phrase 'public space' to refer to the physical spaces of public interaction and 'public sphere' to include nonphysical, mediatised interaction as well. This is distinct from some writers who use 'public space' and 'public sphere' interchangeably, such as Barnett and Low (2004), Benhabib (1992), and Nagel (1995). I also use the term 'space' to denote the physical setting and 'place' to denote the fuller social construct, following Gieryn (2000) and, to a lesser extent, Agnew (1987). This is the opposite usage to that prevalent in some branches of architectural theory, where place denotes the physical form and space denotes the social construct (eg, Rendell, 2008). For further discussion see Parkinson (2012). 
This group of ideas also concerns the roles that people play, exemplified by the common distinction between politicians' private commercial and family interests and their public roles managing collective resources and concerns.

(4) Things which are owned by the state or the people in (3) and paid for out of collective resources like taxes, versus things and places that are individually owned, including things that are cognitively 'our own', like our thoughts, goals, emotions, spirituality, or preferences.

The important point to note about this list is that a particular practice might be public on one ground but not on others; it might have a mix of public and private features. To see this, take the example of ownership. For classical liberal political theorists the right to limit access to a thing flows from ownership of that thing, so that individual ownership defines whether something is private or not (Pennock, 1980; cf Christman, 1994, page 6). However, it is possible to think of counterexamples. In Britain national parks are made up of privately owned parcels of land, but people have the right to wander across that land uninvited and with remarkably few restrictions. Equally, there are buildings and spaces that are public in the sense that they are owned by the state and consume common resources, but to which there are more limited rights of entry: national parks in most other countries, military facilities, the offices of government departments, and even legislatures. The point is not about the limits of ownership rights; it is that many phenomena cannot be labelled wholly public or wholly private. Similarly, ownership and common impact do not track each other neatly. There are many things that are not owned by the state but which nonetheless use common resources, provide public goods, or have public impacts, such as transport systems, heavy industrial facilities, and pension funds. The same is true for any other pair of these categories. The categories are logically distinct, despite the fact that we habitually bundle them together under a single label.

The observation that things can be public when one considers one set of attributes and private when one considers another has important implications for my present purposes. It is likely that any given space could be public in several senses or just in one. This means that we ought to avoid neatly dichotomous definitions of anything that is claimed to be public or private, space included. How, then, should we make sense of the category 'public space'? In the next section I go into that in a little more detail, before taking Geuss's advice and setting out what public space might mean in a specific, political context.

\section{Defining physical public space}

So far, the discussion has shown that there are four broad ways in which something might be public. I do not claim that these four categories are exhaustive or that one could not make more, finer-grained distinctions, but to do so we need to step down a level of abstraction. In this section I take the four categories and examine how they apply in the specific context of space.

The first category of public set out in the previous section is itself spatial, freely accessible space, particularly space in which we encounter strangers, and it is this approach to defining public space that we find most often in the literature. Even in work that explicitly challenges liberalism, the dominant definition of public space is nonetheless based on the classic liberal distinction between a realm of individuals, their minds, bodies, family, and property; and a common realm of streets, plazas, parks, malls, and buildings where access is unrestricted and strangers interact with each other (Kohn, 2004; Madanipour, 2003). Indeed, in some branches of the literature interaction with strangers is taken to be emblematic of public space, contrasted to the world of the home, family, friends, and those one chooses to invite and interact with (Lofland, 1998, pages 7-8). Approaches to what lies between such spaces vary. On the one hand, there are those like Lofland (page 10) who uses the term 'parochial' to denote spaces for repeated interactions between neighbours and acquaintances in relatively 
local communities. On the other there are those like Benjamin (1999) who famously focuses on liminal spaces where the private and the public are said to collide, such as European city arcades in which privately owned buildings arch over publicly accessible footpaths. For many writers it is at these boundary points between public and private space where much of the conflict they study arises (Dovey, 1999); for others it at these points that citizens can make their voices heard, and the creativity of collective life emerges (Franck and Stevens, 2007; Lehtovuori, 2010; Oldenburg, 1997).

This first account of public space raises three issues. The first two are difficulties internal to the account itself, and are to do with the emphasis on strangers and unscripted encounters. First, the strangers motif is often discussed in terms of absence of choice, but in family groups there is no aspect of choice either, yet family is always included on the private side of the ledger. So, choice cannot be the defining element of private space, nor its lack definitive of public. Second, there are many kinds of public events in public space that are highly scripted and impose quite rigid standards of behaviour, well beyond everyday norms and boundaries. Think, for a moment, of major ceremonial events in which the rituals of membership of a given polity are acted out (Goodsell, 1988). Spaces that are used for national events often come with reserved norms of behaviour even when not being used for formal events. This does not mean there should be no room for challenges to the rules, on the one hand, or good old playfulness, on the other (Stevens, 2007). But even if we bracket off such 'exceptional' events, there are the cultural scripts we follow in daily life as well. Indeed, one of the points insisted on by Simmel, Goffman (1963), Lofland, and others is that the urban experience is characterised by everyday rituals of civility, which ensure that one's freedom does not conflict too much with others' - a classically liberal position, by the way (Rawls, 1971). The point is that there are scripts for encounters in public space, rules which do not seem to diminish the 'publicness' of the space.

The third issue concerns the political blind spot of definitions of public space that follow this 'open and accessible' approach. Such definitions are sociological in a very foundational sense. They start their analysis of public space by contrasting it to a private or parochial space of home, family, and community, taking a direct line from Simmel (1950) and Tönnies (1957), who themselves start more or less explicitly with the connectedness of Gemeinschaft, then wander into the city and find that quality replaced by a complex set of rituals, sites, and rules to produce the civility of Gesellschaft. That is very different from the starting point of liberal political theory, and it is worth spelling out that alternative in some detail.

In classical liberal thought the public-private distinction emerges as part of a challenge to the authority of sovereigns, casting the 'problem' of government as how to justify the interference of states and sovereigns in the lives of otherwise-free, 'private' individuals. A legitimate state from this perspective is not so much one that engenders the belief in its legitimacy - the sociological approach to legitimacy advanced by Weber (1965) and perpetuated by empirical political scientists ever since-but one whose rules are either the result of explicit agreement among those subject to them, or tacit agreement founded on authorisation and accountability of rule makers (Ackerman, 1991). In such a context the private sphere is primary, characterised as the 'locus of initiative' in which free individuals make autonomous decisions - while the public sphere is where the conflicts that arise between individual preferences are resolved and the rules of their association defined (Baechler, 1980, page 269). Thus, in liberal political theory 'public' denotes the sphere where individuals themselves or through their duly appointed representatives press claims upon each other; where decisions about resources and resource allocation are made; and where norms are set and values weighed - where politics happens, in other words. 
Precisely where the boundary between public and private and the political and the nonpolitical should lie, though, has long been recognised as problematic. For example, a major strand of feminist political thought has shown how the liberal insistence on the primacy of the private sphere can be used to hide the political dimensions of domestic relationships, which led some to want to push the boundary of legitimate political concern well towards the private end of the scale. In the context of debates about fertility, however, the trend is reversed, with writers arguing instead for strict limits on the degree to which the public can encroach on women's decisions about their bodies (Cohen, 1996). Critical theorists and others have used these kinds of debates to launch a general rethinking of the extent and nature of the public sphere, arguing that it is found not just in formal institutions but in informal ones too - around kitchen tables as well as in kitchen cabinets - and that it might be more accurate and more normatively desirable to talk of numerous public spheres in the plural rather than assuming a single, all-inclusive public sphere. ${ }^{(2)}$

This difference between the sociological and political starting points matters a great deal, because it has a big impact on analyses of the democracy's spatial requirements. With few exceptions (eg, Barnett, 2003; Iveson, 2007), when urban sociologists and human geographers write on democracy and public space they either do not specify what they mean by democracy at all (eg, Benton-Short, 2007) or use the word democracy to mean a particular kind of negative liberty - the absence of interference in the pursuit of goals. While there is certainly a case for thinking that liberty thus conceived is an essential element of a democratic order (Rawls, 1996), it hardly exhausts the list of requirements. By contrast, political and policy scientists tend to start from the view that democracy is a way of sorting out the conflicts that arise between individuals pursuing their own ends: questions about how to distribute resources ${ }^{(3)}$ or, in Laswell's (1958) famous phrase, "who gets what, when and how"; the interests and power relations that structure that distribution; and the normative issues of who should get what, and how to structure society so that they get it. We can see the difference this makes by considering the spatial analogues of the other kinds of 'public' noted in the previous section. If we think politically, then these spaces include:

- monuments and streetscapes where the demos represents itself to itself, anchoring identities and memories (Till, 2005);

- spaces owned by 'the public' for other collective purposes, such as security, education, information sharing, recreation, and amenities like cemeteries, transport and other infrastructure, libraries, or public toilets;

- and the spaces for the performance of political roles like public claim and decision making, representation, collective decision making, and scrutiny (Parkinson, 2013).

In the next section I go into more detail on the last item on that list - the sites of democratic performance. But for the moment it is worth summing up where we have got to with a definition of public space. By analysing the ideas masked by the public-private distinction, and bringing in a political account of the public, public space has been expanded to mean three things:

a. openly accessible space; and/or

b. space of common concern (in terms of using common resources or having common effects); and/or

c. space used for the performance of public roles.

${ }^{(2)}$ See Benhabib (1996) and Fraser (1992). On the spatial emplacement of gender relations see Colomina (1992) and Wilson (1991).

${ }^{(3)}$ By 'resources' I mean things like time, money, and various physical goods, but also information and information technology; welfare-related goods like health and happiness; abstract goods like ability, opportunity, autonomy, and liberty; or symbolic resources like national buildings, plazas, flags, and centres of public action. 
Some space can be public in all three senses, like large central plazas. It can be public in just two of the senses, like recreational and other 'public' facilities (senses a and b) or legislatures (senses $\mathrm{b}$ and $\mathrm{c}$, but with access ranging from strictly limited to completely closed). Or it can be public in just one of the senses, including privately owned and tenanted skyscrapers (sense b). Examples of space that is public in only sense c might include privately owned locations that are used for public purposes, such as the conversations about collective matters that go on every day around the kitchen table, whether among family and friends or among dissidents gathered away from the watchful eye of the state - the activity determining the publicness of the space more than any intrinsic features of the space itself (Benhabib, 1992, page 78; Gieryn, 2000; Mansbridge, 1999).

This definition of public space is more nuanced than that which dominates the literature at present. While the empirical work of geographers and urban sociologists certainly look at practices of all three kinds, the dominant definition of public space focuses on type a. Political theorists, to the extent that they notice it at all, sometimes discuss type b (although not in such terms) but surprisingly rarely consider type c; type a is not on their radar at all. Planners and city development officers tend to focus on a and b but miss type c, especially space required for the performance of political roles. My task in section 4 is to develop the account of type c, and I do so by focusing on the democratic roles.

\section{Democratic public space}

'Public roles' in the definition of type c space could cover a wide range of practices, but in a democracy particular roles are emphasised. Drawing on recent accounts of public claim making, representation, the performance of roles, and the 'division of labour' in a democracy (Hajer, 2009; Parkinson, 2006; 2012; Parkinson and Mansbridge, 2012; Rehfeld, 2009; Saward, 2006; Young, 2000), the main roles are:

- articulating interests, opinions, and experiences;

- making public claims:

defining collective problems or defending existing arrangements,

requesting action or inaction on collective problems,

expressing, setting, and defending norms, and

making claims on public resources;

- deciding what to do, or what not to do, to address public claims, including weighing up options;

- scrutinising and giving account for public action and inaction.

- representing experiences, opinions, and interests, including making, checking, and challenging claims to represent.

The performance of the roles requires physical engagement (Parkinson, 2009). First, the narrative and deliberative phases of democracy work best when conducted face to face, because it increases civility and allows the nonverbal cues to be transmitted and received (Gutmann and Thompson, 1996; Kock, 2007). Second, it is important that claim makers should be seen in dignified, symbolically rich public space so that their claim making is made obvious to other citizens; in order to demonstrate to decision makers the scale of public displeasure; and so that claim makers themselves get the sense that they are not alone- $\mathrm{a}$ sense of political efficacy depends on that. Third, a sense of inclusion and membership of the demos is enhanced when one sees one's narratives anchored in symbolic, physical form. Even the presence of the marginal in public places is a necessary (but not sufficient) condition for them to feel and be recognised as fellow claim makers by other members of the demos (cf Mitchell, 1995). Fourth, the physical performance of decision making helps attentive public perform their scrutiny role (Hindson and Gray, 1988). Virtual decision making can too easily become hidden, back-room decision making. Forcing decision makers into public view helps 
force decision making into public view, with all the deliberative benefits of publicity that follow (Gutmann and Thompson, 1996).

Now, crucially, some roles require very particular kinds of space, something that Kenneth Burke (1969) calls the 'scene-act ratio'. Hajer (2005) claims that it is meaningless to seek a general account of links between political roles and their appropriate stages, because what links scene and act is highly variable and context dependent. I disagree: high variability does not mean that there are no limits within which the variation takes place, and we can theorise what those limits might be.

The first democratic role is narrating political issues, distributing opinion and political 'storylines' (Hajer, 1993) throughout a democratic society. When it comes to spatial performance of this role, the limits are very wide indeed. Narration takes place in all sorts of settings: in the informal public sphere it happens in homes, pubs, clubs, at work, in the street, and wherever people interact (Mansbridge, 1999); in the formal public sphere it happens when witnesses are called to give evidence to parliamentary committees, or when representatives narrate stories about the impact of policy on their constituents. It happens virtually too, of course, but it happens in physical settings as well.

An important point arises here. Private political narrative is more than casual interaction, something that is indicated by the frequently encountered taboos in many cultures about discussing certain topics with strangers. Most private talk is about establishing social bonds, not sorting out the problems of the world. When we expect narration to happen across boundaries of experience and enclave, or when we expect conflict to arise - in other words, and according to liberalism, those topics that are 'political' by their very nature-we tend to move narration to designated settings where conflict can be encouraged yet contained, to place it on a slightly more formal footing or a more formal setting, with rules of engagement to civilise conflict. Those rules can be hierarchical and formal or fairly egalitarian (Dryzek, 1987). Thus the limits of the scene-act ratio when it comes to the narration of experience depend on whether the experience being narrated involves conflict with others present at the same time, which in turn depends on local norms about what constitutes acceptable and unacceptable topics of normal, unmediated interaction.

The second democratic role, making public claims, has much in common with narration, and thus shares elements of its scene-act ratio. However, the specific act of making public claims requires that the rest of the public is paying attention somehow, and that implies another set of restrictions on the range of possible settings. Simply talking among yourselves in out-of-the-way places will not do: getting noticed and taken seriously is what matters, which means that claims need to be made in publicly visible and accessible places (Mitchell and Staeheli, 2005, page 798). Most obviously, groups can organise demonstrations at sites of power or sites of symbolic importance, perhaps adding a march from one site to another. The more people who turn out, the bigger the impact, because numbers are a proxy for the significance of a point of view. It could involve spaces that the media regularly monitor anyway, because they are spaces where the powerful and decision makers gather. It could involve stunts designed to attract the television cameras. For all these approaches, visibility is paramount.

In the case of representative institutions, the setting range is narrower again. We need not get quite so carried away as Edmund Burke, who thought that a deliberative assembly should be

"imposing and majestic. It should overwhelm the imagination of the populace, and awe them into acquiescence. The arena should be the architectural summit of human achievement, vast, impressive and sublime" (Hindson and Gray, 1988, page 31).

It is possible, for example, to stage binding collective decision making in much less grandiose style, as the Swiss cantons of Appenzell Inner-rhodes and Glarus do at their annual outdoor 
Landsgemeinden, held in the main town square each Spring (Reinisch and Parkinson, 2007). Nonetheless, even though the Landsgemeinden take place outdoors, they are still ritualised, physical assemblies that take place in a single location. This is important for two reasons. The first is that the staging signals to people that the event matters - that the decisions reached there have an impact on thousands, even millions, of people. The rituals of seriousness cue us in to taking the proceedings seriously (Rai, 2010). The second reason is hinted at by something else E Burke says: that being a member of a legislature means that one is "on a conspicuous stage, and the world marks our demeanour" (quoted in Hindson and Gray, 1988, page 21). When considering the scrutiny role of democracy, it is a significant advantage to have a single, readily identifiable, and prominent stage, because it puts the powerful under the spotlight and keeps them there.

To conclude this section, it is worth stressing two normative requirements for democratic public space that arise from this discussion. The first is that there be a single or small number of visible, publicly accessible, and dignified stages for the making, testing, and justification of decisions by elected representatives. The second is that there be visible and relatively uncluttered open space available in or near that same dignified space for public claim making. The former is important for several reasons, but particularly to allow the scrutiny role to be performed effectively. The latter is crucial both for the benefits that accrue to citizens themselves - constituting themselves as an active, purposive public; gaining a sense of efficacy; seeing that others feel like they do-and for the status of citizens and citizens' claims in the public sphere, cloaking public claims and public claim making in the symbols of dignity, as well as the more specific value of impressing on leaders the scale of public displeasure.

But for that latter requirement to work, the available space needs to be relatively large, open, and uncluttered by trees and urban furniture. To get a sense of how important this requirement is, consider the case of Hong Kong - where Chater Gardens and Statue Square, the two public spaces around the Legislative Council building, were rebuilt in the 1970s to provide a lot of seating and conversational space. As Law (2002) argues, they are thus great spaces for narrating experience among a subaltern group, but those same features make them bad for demonstrating the scale of public displeasure because they break crowds into small, policeable chunks. Protest marches in Hong Kong have an obvious assembly point for around a hundred thousand people in Victoria Park, Causeway Bay; they have an obvious marching route, the three kilometres down Hennessy Road and Queensway into Central; but they have no obvious terminus, because Chater Gardens can hold only about 5000 people in discrete little pockets; there is nowhere to stop outside the Chief Executive's residence on Upper Albert Road, and there is nothing but slip road and motorway outside the office tower housing the Central People's Government Liaison Office further west in Sheung Wan. This allows ruling elites in Hong Kong to distance themselves from the people they are supposed to be serving, and impacts on the degree to which people feel their views are taken seriously (Parkinson, 2012). While Chater Gardens might aid unplanned (as opposed to unscripted) encounters between denizens, it is an active barrier to public-driven encounters between the masses and their rulers.

Hong Kong is a system with only limited democratic features. More challenging tests of the importance of these concepts should come from the capital cities of established democracies. In the final section I look at how these ideas play out in the City of Westminster, one of the constituent boroughs of Greater London, and the borough in which Parliament and most government departments reside. Through a very simple content analysis of three planning documents, I show how democratic values are almost entirely absent from key decisions around public space in a city that some claim to be the very home of democracy. 


\section{Case study: the meaning of public space in Westminster}

London has been the scene of intense battles over the right to protest outside Parliament. In 2001 a lone protestor, Brian Haw, set up a peace camp on the grass of Parliament Square to protest about the deaths of children in Iraq thanks to international sanctions. ${ }^{(4)}$ Over the next decade central and local government tried to remove the camp with its tents, huge numbers of placards, and day-and-night loudhailer harangues of parliamentarians and passers-by. While sometimes bordering on the farcical (eg, Ireland, 2008; Thomas, 2007), efforts to ban this and to get similar camps removed eventually succeeded; and while there have been several attempts to repeal some of the restrictions, bills have stalled several times in Parliament at the same time as other legislation has strengthened rather than weakened the controls. ${ }^{(5)}$

Counterposed to the demands of activists and civil liberties groups has not just been the security issues, but a set of claims about the heritage and dignity of the site; about peaceful working and enjoyment; about traffic and pedestrian disruption; about disruption to tourists; and about making the site available for 'all users'-a motif discussed shortly. One of the means of making the site available to all users is to enhance access to the square to "make it easier for people to get closer to the square's statues and to secure better viewing points to take pictures of the Palace of Westminster" (Westminster, 2011a, unpaginated). Another has been a series of proposals - some implemented, others quietly dropped - to redesign the square with more furniture, pools, levels, and plantings, to make it work better as a place for accidental interactions (GLA, 2009a; Hunt, 2008), but which, as suggested by the Hong Kong case, would undermine its usefulness as a terminus for mass protest.

It is therefore instructive to examine official discourse around the site and see how public space is defined ten years on, what values are bundled up with the label, which agents are recognised, and whether the sites that are normatively valuable for democracy are recognised as such (Fairclough, 2003). To do this I have conducted a simple content analysis of the key planning documents that concern the central parliamentary zone:

(1) The Greater London Authority London Plan (GLA, 2009b). This document is designated "Mayor" in the table and figures that follow.

(2) A response from the GLA (2011) Planning and Housing Committee to the draft mayoral plan. This is designated "Assembly" in the table and figures.

(3) The Local Development Framework Core Strategy from the City of Westminster Council, which is the local response to the overall GLA plan (Westminster, 2011b). This is designated "Westminster" in the table and figures. ${ }^{(6)}$

I started the analysis by creating a simple coding frame which was developed in an open, document-directed fashion, supplemented by concepts that are core to my normative framework-it thus has both grounded and theory-driven elements (Berg, 2001). The frame was then applied to the three texts to generate a word-frequency table (see table 1). From these word frequencies some fascinating results emerge.

The first graph (figure 1) shows the differing conceptions of 'public' and 'public space'. Nearly half (47.8\%) of the total mentions of public in the Mayor's plan are to do with public

${ }^{(4)}$ Kerslake (2010) provides a detailed day-by-day history of the camp, with links to media and blog stories on events. Brian Haw died on 18 June 2011.

${ }^{(5)}$ See details of the passage of the Police Reform and Social Responsibility Act 2011, available from http://services.parliament.uk/bills/2010-11/policereformandsocialresponsibility.html, with links to amendments, committee hearings, and submissions.

${ }^{(6)}$ The websites of other organisations with Parliament Square responsibilities were also searched for relevant planning and policy documents, but no other extended discussions were found. Those other organisations include: the Metropolitan Police; the Ministry of Defence Police (which sometimes has Government Security Zone responsibilities); the Cabinet Office; the Serjeant-at-Arms of the House of Commons; and the Dean and Chapter of Westminster Abbey. 
Table 1. Coding frame and word frequencies.

\begin{tabular}{|c|c|c|c|}
\hline & Westminster & Mayor & Assembly \\
\hline Concepts: public & 176 & 282 & 306 \\
\hline Public transport & 27 & 130 & 0 \\
\hline Public space & 6 & 13 & 167 \\
\hline Public realm & 35 & 42 & 97 \\
\hline Open space & 108 & 97 & 42 \\
\hline Security & 155 & 275 & 65 \\
\hline Safety & 71 & 131 & 16 \\
\hline Security & 42 & 118 & 42 \\
\hline Crime/criminal & 37 & 19 & 2 \\
\hline Terror/terrorism/terrorist & 5 & 7 & 5 \\
\hline Economy & 179 & 417 & 13 \\
\hline Economy/economic & 129 & 278 & 8 \\
\hline Jobs & 25 & 64 & 4 \\
\hline Competitiveness & 10 & 34 & 0 \\
\hline Global & 15 & 41 & 1 \\
\hline Recreation, heritage & 154 & 213 & 37 \\
\hline Play and games & 24 & 37 & 18 \\
\hline Olympic Games & 6 & 43 & 2 \\
\hline Recreation & 12 & 49 & 10 \\
\hline Tourist/tourism & 37 & 28 & 1 \\
\hline Heritage/history & 75 & 56 & 6 \\
\hline Democracy & 1 & 0 & 5 \\
\hline Democracy & 1 & 0 & 3 \\
\hline Protest/demo/rally & 0 & 0 & 2 \\
\hline Health and Amenity & 96 & 221 & 12 \\
\hline Beauty & 0 & 2 & 0 \\
\hline Health & 75 & 157 & 6 \\
\hline Quality of life & 8 & 59 & 6 \\
\hline Peace/tranquil & 13 & 3 & 0 \\
\hline Environment & 182 & 362 & 41 \\
\hline Green & 50 & 107 & 13 \\
\hline Environment & 132 & 255 & 28 \\
\hline Social/society & 98 & 157 & 10 \\
\hline Agents & 180 & 239 & 51 \\
\hline Citizen/citizenship & 0 & 2 & 5 \\
\hline Consumer & 2 & 5 & 0 \\
\hline User & 4 & 17 & 17 \\
\hline Business & 109 & 125 & 20 \\
\hline Government & 65 & 90 & 9 \\
\hline Sites & 9 & 7 & 0 \\
\hline Palace of Westminster & 4 & 3 & 0 \\
\hline Parliament & 5 & 3 & 0 \\
\hline Parliament Square & 0 & 1 & 0 \\
\hline
\end{tabular}




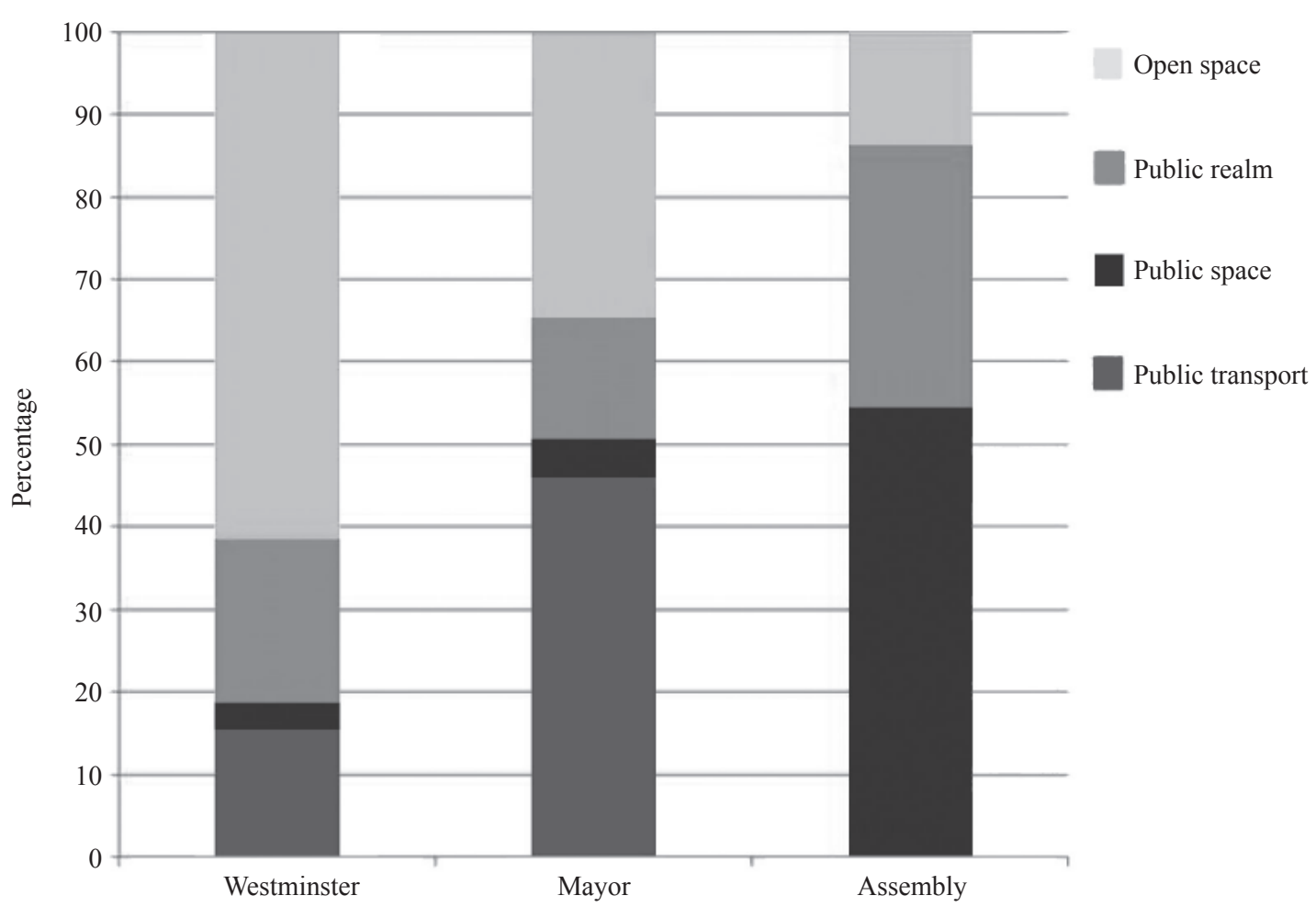

Figure 1. Definitions of public space.

transport, compared with $15.3 \%$ of mentions in the Westminster document and none in the assembly response. But just as striking is the fact that 'open space' dominates the mayoral and Westminster documents, while 'public space' dominates the assembly, followed by 'public realm'. These terms have a precise meaning in British planning policy (GLA, 2011, appendix 1). Open space means publicly accessible space without any formal facilities for recreation - open, green parks, essentially - and is a term that dates from the Town and Country Planning Act 1990 (section 336, interpretation). The public realm and public space are usually treated as synonymous, and are more recent concepts meaning:

"all those parts of the built environment where the public has free access. It encompasses:

all streets, squares, and other rights of way, whether predominantly in residential, commercial or community/civic uses; the open spaces and parks; and the 'public/private' spaces where public access is unrestricted (at least during daylight hours). It includes the interfaces with key internal and private spaces to which the public normally has free access" (ODPM, 2004, page 10).

In other words, public space for London's planners clearly means type a, open and accessible space; and implicitly elements of type b, space of common concern, as will be seen when discussing the values bound up with the concept; but not type $\mathrm{c}$, space for the performance of public roles, including democracy.

Type c gets a mention, but only just, as can be seen when we look at the values and agents that are recognized in the documents. Starting with agents, figure 2 shows the relative frequency of mentions of government, business, and three different constructions of nonelites: citizen, consumer, and user. The point to note here is that 'citizens', the democratic role of active claim makers, barely get a mention (just two mentions in the mayoral document, five in the assembly document, and none at all in Westminster document). 'Users' do not fare much better in the Westminster and mayoral documents, but account for a third of the recorded mentions of agents in the assembly report. Before we think that that is cause for celebration, however, it needs to be remembered that the 'user' frame is deployed to crowd out the claims of 'citizens' (Barnes, 1997; Scourfield, 2007), and that space that is good for one set of users 


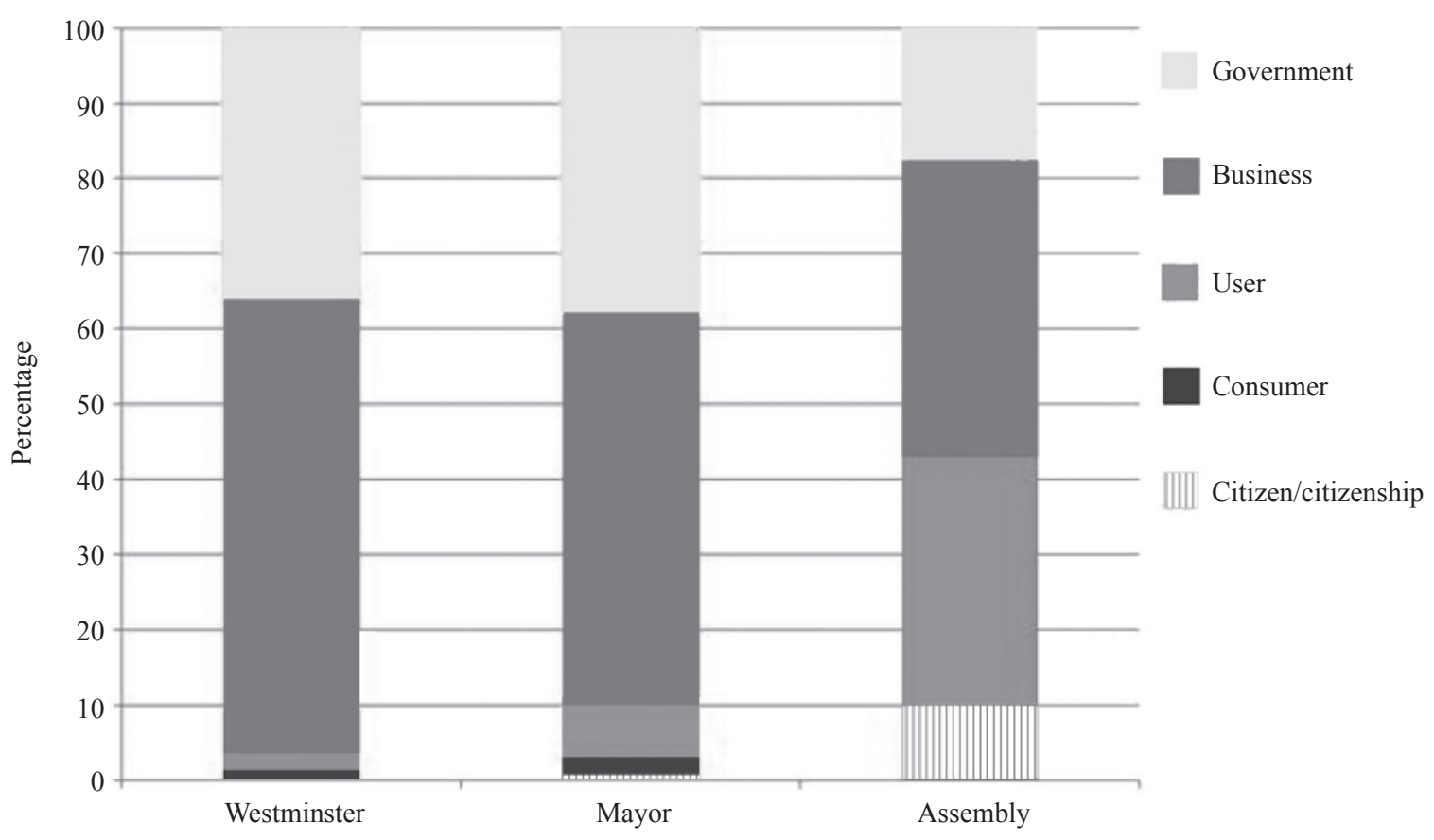

Figure 2. Agents in public space.

is not necessarily good for others. Space that is good for tourists and appreciation of a city's heritage is not necessarily good space to stop and sit with a book and a sandwich. Space that is good for stopping at lunch time is space with lots of trees and urban furniture (Sennett, 2002), but that is space that is less good for packing in crowds of protestors.

The point to stress here is that a single space cannot possibly meet all the demands that might be placed on it, so some needs are prioritised over others. Despite the two plans' emphasis on 'multifunctionality' (GLA, 2009b, page 57) and "the needs of all" (Westminster, 2011b, page 96) - an outgrowth of the place-shaping and 'liveability' agendas of the last decade or so (Gallent and Wong, 2009) - the kinds of spaces that policy makers in London are actually advocating privilege tourists, shoppers, and lunchtime crowds over democratic claim makers. Indeed, this is part of a general trend: the systematic, discursive privileging of accidental publics - the 'unscripted encounters with strangers' kind of public, the 'communities' kind of public, and the 'shoppers' kind of public_-over purposive publics made up of citizens expressing or canvassing views (Allmendinger and Haughton, 2010; Barber, 2001; Kohn, 2001; Parkinson, 2012). The irony is that this is the kind of move that the writers of the assembly report are so keen to resist. They want to promote democratic space; but by working with too-simple concepts of democracy, public, and public space they fall into language and practices that reinforce the provision of space, for accidental rather than purposive publics.

This view is reinforced by looking at the values associated with public space in the three documents. In figure 3 we see the comparative weights given to different values, and here the most striking feature is that word 'democracy' appears not once in the mayoral plan, once only in the Westminster local plan, and just twice in the assembly report, where it is associated with accessibility of space (type a) rather than public claim making (type c). The words 'demonstration', 'rally', and 'protest' appear only in the assembly document, and even then appear just once each. Security concerns appear much more often, more so even than in the mayoral and Westminster documents, which in turn spend considerably more space on economic and environmental values, as well as health and 'amenity'-something that covers broad considerations of liveability, peace, tranquillity, and visual beauty. 


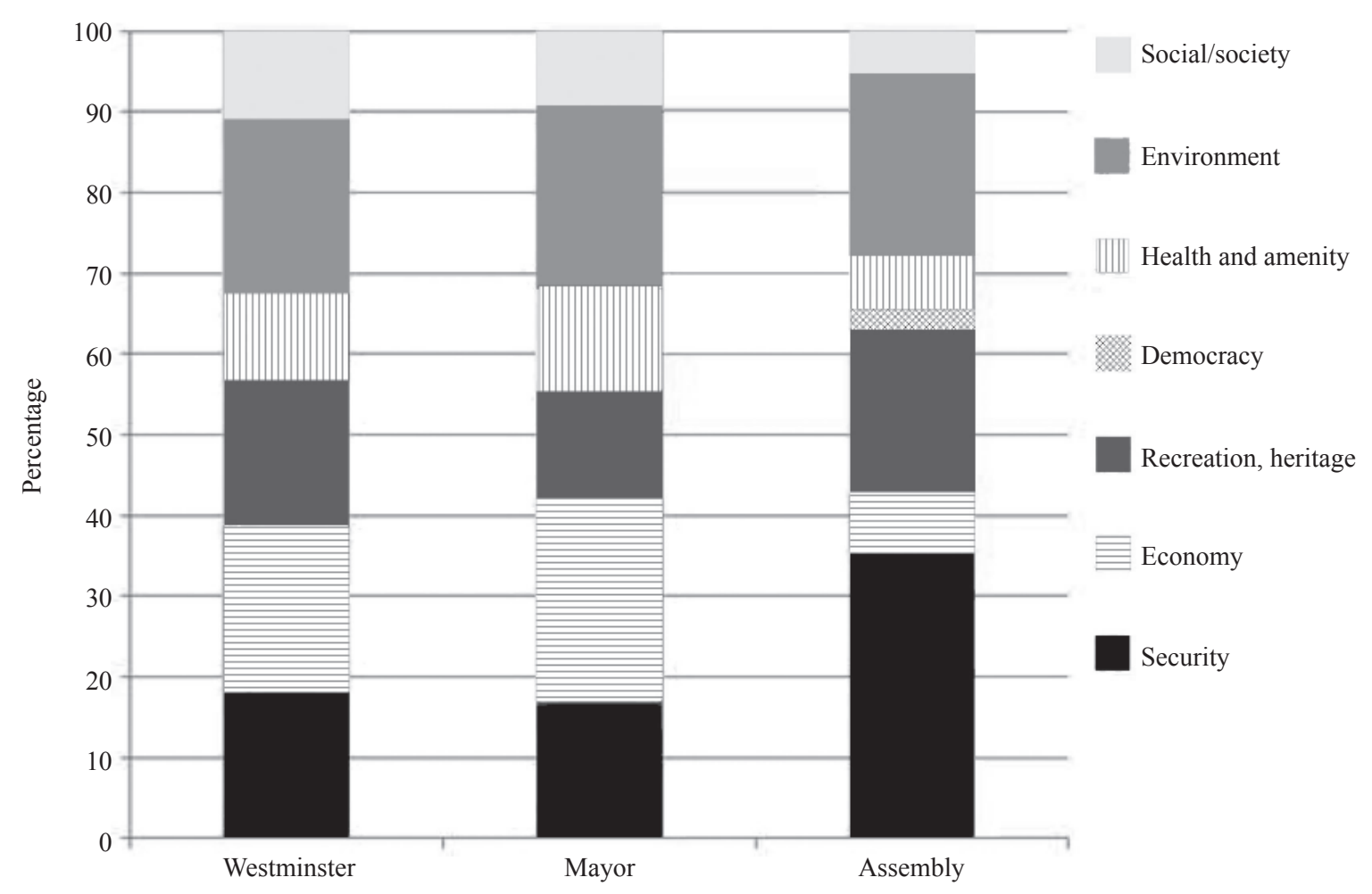

Figure 3. Values of public space.

That visual beauty aspect of public space is connected most strongly with 'heritage' values in the Westminster plan. Throughout the document the key challenge is creating spaces for the 230000 residents that are 'tranquil' at the same time as managing the influx of a million daily visitors. Visual amenity is clearly key, for economic reasons:

"They are cherished for their aesthetic qualities as well as the links they provide to the past and sense of place they create. Westminster's historic environment makes an essential contribution to the local, regional and national economy and is fundamental to its success in a global economy. The historic environment is identified as a key reason why businesses and institutions choose to locate within Westminster, and it is also vital to the millions of tourists who come every year to enjoy the city's exceptional heritage" (Westminster, 2011b, page 91).

Given that, both the Westminster and mayoral plans spend a considerable amount of space on listing and protecting 'designated views'. This is connected with the parliamentary site's status as a World Heritage Site, something that drives efforts to protect particular panoramas from building and development that would diminish the view's value to both tourists with cameras and locals' ability to develop a sense of pride and belonging (GLA, 2009b, policy 7.12), and drives politicians' and planners' efforts to remove the Peace Camp on aesthetic grounds rather than protecting it on democratic ones.

In sum, it is evident from even the simplest of content analyses that a limited construction of public purposes and public spaces overwhelmingly dominates official planning policy in London. It is a discourse that emphasises accidental, social, recreational, and commercial publicness over purposive, political, and democratic publicness, with security, health, heritage, and certain kinds of environmental values dominating practical politics. This discourse is being built into the physical environment of the City of Westminster, such that public space type c, space for the making of public claims, is under enormous, state-sponsored pressure. 


\section{Conclusions}

One could conduct a similar analysis in the capital cities of other established democracies and find similar patterns. In Washington, DC one finds security, tourism, heritage, public ritual, commerce, and democracy colliding on a daily basis in the National Mall (BentonShort, 2007). In Canberra fights occasionally break out over control of dignified political space between security and parliamentary interests, on the one hand, and aboriginal and other activists, on the other (Parkinson, 2012; see also Vale, 2008). The central claim of this paper is that the standard academic definition of public space does not provide a strong enough normative foundation on which to build an effective challenge by those who would open up such spaces for more direct political engagement.

Space can be public in three major ways, but spatial policy is dominated by just one of those conceptions - open and accessible space - to the exclusion of space for the making of public claims. It thus supports spatial policies that privilege the needs of casual, accidental crowds over organised, purposive groups of democratic claim makers. This is because a given space cannot possibly meet all the requirements of all different 'users' at once, and so the emphasis on 'all users' masks the exclusion of citizens acting en masse from public space. Ironically, the very effort to produce space for unplanned encounters between some kinds of people privileges 'users' over citizens performing specific democratic roles and obscures the growing barriers between rulers and ruled. By contrast, the three-fold understanding of public space advanced here alerts us to the fact that while some kinds of space can support all sorts of democratic and collective action, many cannot, and so we need to think about the overall provision of kinds of public space in cities rather than imposing a single set of design imperatives on spaces like Parliament Square. To do the latter, I think, is to undermine one of the important things that scholars of public space say they want to preserve: space for democracy.

It is not my purpose in this paper to deny the importance of a conceptual emphasis on equality and encounters between strangers. Indeed, that body of work has been very important in highlighting the daily exclusions of modern cities, where certain kinds of consumer are privileged over communities, over the poor and marginal. However, community and liberty are not the sum total of democracy. Democracy is a claim-making and decision-making enterprise as much as a set of social and cultural conditions, and one that sometimes requires mass action as well as small-scale discussion. For the mass democratic roles to be performed, space of particular kinds is required, including relatively large, open, and unimpeded space next to the symbolic and political centre of a state. It is that kind of space that is under threat from modern spatial policy, and that kind of space that is not recognised by currently orthodox definitions of public space.

Acknowledgements. Much of the research for this paper was funded by the British Academy (SG44244), support I gratefully acknowledge. My thanks also to the journal's editors and referees whose critical engagement with the first draft considerably strengthened the final version, and to my colleagues at the University of Warwick for their criticisms and support, especially Matthew Clayton, Shirin Rai, and Richard Aldrich.

\section{References}

Ackerman B, 1991 We the People 1: Foundations (Harvard University Press, Cambridge, MA)

Agnew J, 1987 Place and Politics: The Geographical Mediation of State and Society (Allen and

Unwin, Boston, MA)

Allmendinger P, Haughton G, 2010, "Spatial planning, devolution, and new planning spaces"

Environment and Planning C: Government and Policy 28 803-818

Arendt H, 1958 The Human Condition (University of Chicago Press, Chicago, IL)

Baechler J, 1980, "Liberty, property and equality", in Property: Nomos 22 Eds J R Pennock,

J Chapman (New York University Press, New York) pp 269-288 
Baker M, Hincks S, Sherriff G, 2010, "Getting involved in plan making: participation and stakeholder involvement in local and regional spatial strategies in England" Environment and Planning C: Government and Policy 28 574-594

Barber B, 2001, "Malled, mauled and overhauled: arresting suburban sprawl by transforming suburban malls into usable civic space", in Public Space and Democracy Eds M Hénaff, T Strong (University of Minnesota Press, Minneapolis, MN) pp 201-220

Barnes M, 1997 Care, Communities and Citizens (Longman, London)

Barnett C, 2003 Culture and Democracy: Media, Space and Representation (Edinburgh University Press, Edinburgh)

Barnett C, Low M, 2004 Spaces of Democracy: Geographical Perspectives on Citizenship, Participation and Representation (Sage, London)

Benhabib S, 1992, "Models of public space: Hannah Arendt, the liberal tradition, and Jürgen Habermas", in Habermas and the Public Sphere Ed. C Calhoun (MIT Press, Cambridge, MA) pp 73-98

Benhabib S, 1996 Democracy and Difference: Contesting the Boundaries of the Political (Princeton University Press, Princeton, NJ)

Benjamin W, 1999 The Arcades Project (Harvard University Press, Cambridge, MA)

Benton-Short L, 2007, "Bollards, bunkers, and barriers: securing the National Mall in Washington, DC" Environment and Planning D: Society and Space 25 424-446

Berg B L, 2001 Qualitative Research Methods for the Social Sciences (Allyn and Bacon, Boston, MA)

Burgess J, Harrison C, Limb M, 1988, “People, parks and the urban green: a study of popular meanings and values for open spaces in the city" Urban Studies 25 455-473

Burke K, 1969 A Grammar of Motives (University of California Press, Berkeley, CA)

CABE, 2002 The Value of Good Design: How Buildings and Spaces Create Economic and Social Value Commission for Architecture and the Built Environment, London

Christman J, 1994 The Myth of Property: Toward an Egalitarian Theory of Ownership (Oxford University Press, Oxford)

Cohen J, 1996, "Democracy, difference, and the right of privacy", in Democracy and Difference: Contesting the Boundaries of the Political Ed. S Benhabib (Princeton University Press, Princeton, NJ) pp 187-217

Colomina B, 1992 Sexuality and Space (Princeton Architectural Press, New York)

Dewey J, 1924 The Public and its Problems (Holt, New York)

Dovey K, 1999 Framing Places: Mediating Power in Built Form (Routledge, London)

Dovey K, 2004 Fluid City: Transforming Melbourne's Urban Waterfront (Routledge, London)

Dryzek J, 1987, "Complexity and rationality in public life" Political Studies 35 424-442

Fairclough N, 2003 Analysing Discourse: Textual Analysis for Social Research (Routledge, London)

Franck K, Stevens Q, 2007 Loose Spaces: Possibility and Diversity in Urban Life (Routledge, Abingdon, Oxon)

Fraser N, 1992, "Rethinking the public sphere: a contribution to the critique of actually existing democracy", in Habermas and the Public Sphere Ed. C Calhoun (MIT Press, Cambridge, MA) pp 109-142

Gallent N, Wong C, 2009, "Introduction: place shaping, spatial planning and liveability" The Town Planning Review 80 353-358

Geuss R, 2001 Public Goods, Private Goods (Princeton University Press, Princeton, NJ)

Gieryn T F, 2000, “A space for place in sociology” Annual Review of Sociology 26 463-496

GLA, Greater London Authority, London

2009a, "Improving the square", http://www.london.gov.uk/parliamentsquare/improve/index.jsp

2009b The London Plan: Spatial Development Strategy for Greater London (Consultation Draft Replacement Plan) October 2009

2011, "Public life in private hands: managing London's public space", Planning and Housing Committee, London Assembly

Goffman E, 1963 Behavior in Public Places: Notes on the Social Organization of Gatherings

(Free Press, New York) 
Goodsell C T, 1988 The Social Meaning of Civic Space: Studying Political Authority Through Architecture (University Press of Kansas, Lawrence, KA)

Gutmann A, Thompson D, 1996 Democracy and Disagreement (Harvard University Press, Cambridge, MA)

Hajer M, 1993, "Discourse coalitions and the institutionalization of practice: the case of acid rain in Britain", in The Argumentative Turn in Policy Analysis and Planning Eds F Fischer, J Forester (Duke University Press, Durham, NC) pp 43-76

Hajer M, 2005, "Setting the stage: a dramaturgy of policy deliberation" Administration and Society 36 624-647

Hajer M, 2009 Authoritative Governance: Policy-making in the Age of Mediatization (Oxford University Press, Oxford)

Hardin G, 1968, "The tragedy of the commons" Science 162 1243-1248

Hindson P, Gray T, 1988 Burke's Dramatic Theory of Politics (Avebury, Aldershot, Hants)

Hunt T, 2008, "Give it back to the people" Guardian 25 June, http://www.guardian.co.uk/politics/2008/jun/25/1

Ireland T, 2008, "My submission to the Home Office for the public consultation on SOCPA", http://www.bloggerheads.com/archives/2008/01/my_socpa_submission.asp

Iveson K, 2007 Publics and the City (Blackwell, Malden, MA)

Kerslake I, 2010, "Parliament Square Peace Campaign: history ...", http://brianhaw.tv/images/pdfs/pspc-history.pdf

Kock N, 2007, "Media naturalness and compensatory encoding: the burden of electronic media obstacles is on senders" Decision Support Systems 44 175-187

Kohn M, 2001, "The mauling of public space" Dissent Spring 71-77

Kohn M, 2004 Brave New Neighbourhoods: The Privatization of Public Space (Routledge, New York) Laswell H, 1958 Politics: Who Gets What, When, How (Meridian, New York)

Law L, 2002, "Defying disappearance: cosmopolitan public spaces in Hong Kong" Urban Studies 39 1625-1645

Lehtovuori P, 2010 Experience and Conflict: The Production of Urban Space (Ashgate, Farnham, Surrey)

Lofland L, 1998 The Public Realm: Exploring the City's Quintessential Social Territory (Aldine de Gruyter, New York)

Madanipour A, 2003 Public and Private Spaces of the City (Routledge, London)

Mansbridge J, 1999, "Everyday talk in the deliberative system", in Deliberative Politics: Essays on 'Democracy and Disagreement' Ed. S Macedo (Oxford University Press, New York) pp 211-239

Mitchell D, 1995, "The end of public space? People's Park, definitions of the public, and democracy" Annals of the Association of American Geographers 85 108-113

Mitchell D, Staeheli L, 2005, "Permitting protest: parsing the fine geography of dissent in America" International Journal of Urban and Regional Research 29 796-813

Nagel T, 1995, "Personal rights and public space" Philosophy and Public Affairs 24 83-107

NCC, 2005 Reflecting a Nation: Creating a Capital Experience for all Canadians National Capital Commission, Ottawa

NCPC, 2005 National Capital Urban Design and Security Plan National Capital Planning Commission, Washington, DC

ODPM, 2004 Living Places: Caring for Quality The Bartlett School of Planning, University College London (Office of the Deputy Prime Minister, London)

Oldenburg R, 1997 The Great Good Place: Cafés, Coffee Shops, Bookstores, Bars, Hair Salons, and other Hangouts at the Heart of a Community (Marlowe, New York)

Parkinson J, 2006 Deliberating in the Real World: Legitimacy Problems in Deliberative Democracy (Oxford University Press, Oxford)

Parkinson J, 2009, "Symbolic representation in public space: capital cities, presence and memory" Representation 45 1-14

Parkinson J, 2012 Democracy and Public Space: The Physical Sites of Democratic Performance (Oxford University Press, Oxford) 
Parkinson J, 2013, "How legislatures work—and should work—as public spaces" Democratization $20438-455$

Parkinson J, Mansbridge J, 2012 Deliberative Systems: Deliberative Democracy at the Large Scale (Cambridge University Press, Cambridge)

Pennock J R, 1980, "Thoughts on the right to private property", in Property: Nomos 22

Eds J R Pennock, J Chapman (New York University Press, New York) pp 171-186

Rai S M, 2010, "Analysing ceremony and ritual in Parliament" The Journal of Legislative Studies $16284-297$

Rawls J, 1971 A Theory of Justice (Oxford University Press, Oxford)

Rawls J, 1996 Political Liberalism (Columbia University Press, New York)

Rehfeld A, 2009, "Representation rethought: on trustees, delegates, and gyroscopes in the study of political representation and democracy" American Political Science Review 103 214-230

Reinisch C, Parkinson J, 2007, "Swiss Landsgemeinden: a deliberative democratic evaluation of two outdoor parliaments", in European Consortium for Political Research Joint Sessions, Helsinki; available from http://www.johnparkinson.net/research1.html

Rendell J, 2008, "Space, place, site: critical spatial practice", in The Practice of Public Art Ed. C Cartiere (Routledge, London) pp 33-55

Saward M, 2006, "The representative claim" Contemporary Political Theory 5 297-318

Schaller S, Modan G, 2005, "Contesting public space and citizenship: implications for neighborhood business improvement districts" Journal of Planning Education and Research 24 394-407

Scourfield P, 2007, "Social care and the modern citizen: client, consumer, service user, manager and entrepreneur" British Journal of Social Work 37 107-122

Sennett R, 2002 The Fall of Public Man (Penguin, London)

Simmel G, 1950, "The metropolis and mental life", in The Sociology of Georg Simmel Ed. K H Wolff (Free Press, Glencoe, IL) pp 409-426

Stevens Q, 2007 The Ludic City: Exploring the Potential of Public Spaces (Routledge, Abingdon, Oxon)

Stevens Q, 2009, “'Broken' public spaces in theory and in practice” The Town Planning Review $80371-391$

Thomas M, 2007, "Demonstrations of victory" The Guardian 26 June, http://www.guardian.co.uk/commentisfree/2007/jun/26/demonstrationsofvictory

Till K, 2005 The New Berlin: Memory, Politics, Place (University of Minnesota Press, Minneapolis, $\mathrm{MN}$ )

Tönnies F, 1957 Community and Society (Gemeinschaft und Gesellschaft) (Harper and Row, New York)

Town and Country Planning Act, 1990 Public General Acts—Elizabeth II chapter 8 (HMSO, London)

Vale L J, 2005, "Securing public space" Places 17 38-42

Vale L J, 2008 Architecture, Power, and National Identity (Routledge, London)

Weber M, 1965 Politics as a Vocation (Fortress Press, Philadelphia, PA)

Westminster, 2011a, "New crossing to reclaim Parliament Square", press release, 7 June, City of Westminster Council, London

Westminster, 2011b Local Development Framework: Core Strategy City of Westminster Council, London

Wilson E, 1991 The Sphinx in the City: Urban Life, the Control of Disorder, and Women (Virago, London)

Young I M, 2000 Inclusion and Democracy (Oxford University Press, Oxford) 